Arq. Bras. Med. Vet. Zootec., v.68, n.4, p.832-838, 2016

\title{
Reproductive biology of Pêga Jackasses: characteristics of sperm-rich fraction collected using the split-ejaculate method
}

\author{
[Biologia reprodutiva de jumentos da raça Pêga: características da fração rica em \\ espermatozoides coletada de forma fracionada] \\ L.E. Carvalho ${ }^{1}$, J.M. Silva Filho ${ }^{2 *}$, M.S. Palhares $^{2}$, A.L.R. Sales ${ }^{1}$, A.T. Gonczarowska ${ }^{1}$, \\ H.N. Oliveira ${ }^{3}$, T. Resende Jr. ${ }^{4}$, R. Rossi ${ }^{1}$ \\ ${ }^{1}$ Aluna de pós-graduação - Universidade Federal de Minas Gerais - Belo Horizonte, MG \\ ${ }^{2}$ Escola de Veterinária - Universidade Federal de Minas Gerais - Belo Horizonte, MG \\ ${ }^{3}$ Escola de Veterinária - UNESP - Jaboticabal, SP \\ ${ }^{4}$ Médico veterinário autônomo - Belo Horizonte, MG
}

\begin{abstract}
The aim of this study was to evaluate the physical and morphological characteristics of the sperm-rich fraction of jackass semen. To this end, 130 ejaculates from five Pêga jackasses were collected using an open model artificial vagina. The sperm-rich fraction was collected using the split-ejaculate method and assessed for the number of mounts/ejaculate, for physical and morphological characteristics of the semen and number of doses produced/ejaculate. It was observed that all characteristics evaluated differed among the five jackasses, except for the head defect rates. The mean values obtained for the jackass sperm-rich fraction collected were: number of mounts/ejaculate - 1.27 ; semen volume - $20.21 \mathrm{~mL}$; motility - $84.53 \%$; vigor - 4.46 ; motility after dilution $80.10 \%$; sperm concentration $/ \mathrm{mL}-894.38 \times 10^{6}$; total sperm/ejaculate - $16.14 \times 10^{9}$; number of insemination doses/ejaculate (400x10 $10^{6}$ motile sptz) - 33.39; number of insemination doses/ejaculate $\left(800 \times 10^{6}\right.$ motile sptz) 16.69 ; and percentage of normal sperm $-90.46 \%$. Thus, in the present experiment the split-ejaculate method using an open artificial vagina worked well with the jackasses, and the sperm-rich fraction of the ejaculate of Pêga jackasses had high quality and sperm concentration, allowing its use for semen processing without reducing the number of insemination doses produced per ejaculate.
\end{abstract}

Keywords: jackass, split-ejaculate method, sperm-rich fraction

\section{RESUMO}

Foram coletados 130 ejaculados de cinco jumentos da raça Pêga, utilizando-se vagina artificial modelo aberta, com o objetivo de se avaliar as características físicas e morfológicas da fração rica em espermatozoides do ejaculado de asininos. Para tal, a fração rica em espermatozoides, composta pelos três primeiros jatos ejaculados, foi coletada e avaliada quanto ao número de montas/ejaculado, quanto às características físicas e morfológicas do sêmen, bem como quanto ao número de doses inseminantes produzidas/ejaculado. Observou-se que todas as características avaliadas diferiram entre os cinco reprodutores avaliados, com exceção do percentual de defeitos de cabeça. Os valores médios obtidos da coleta da fração rica do ejaculado de jumentos foram: número de montas/ejaculado - 1,27; volume de sêmen 20,21mL; motilidade - 84,53\%; vigor - 4,46; motilidade pós-diluição - 80,10\%; espermatozoides $/ \mathrm{mL}$ - 894,38 x

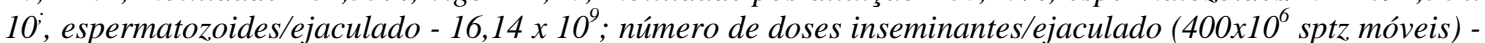
33,39; doses inseminantes/ejaculado (800 × $10^{6}$ sptz/móveis) - 16,69; e percentual de espermatozoides normais - 90,46\%. Assim, no presente experimento, observou-se boa aceitação dos reprodutores à coleta fracionada utilizando-se a vagina artificial aberta, sendo a fração rica do ejaculado de jumentos da raça Pêga caracterizada por alta qualidade e concentração espermática, o que viabilizou sua utilização para o processamento do sêmen, sem prejuízos quanto ao número de doses inseminantes produzidas/ejaculado.

Palavras-chave: jumento, coleta fracionada, fração espermática rica

Recebido em 26 de agosto de 2014

Aceito em 11 de fevereiro de 2016

*Autor para correspondência (corresponding author)

E-mail: silvafilhojm@gmail.com 


\section{INTRODUCTION}

The cooling, storage and transport of semen are important reproductive strategies for many species. Despite the possible participation of seminal plasma constituents in various physiological events, their presence during cooling and cryopreservation seems deleterious to the semen of bulls (Bergeron et al., 2004), stallions (Jasko et al., 1992) and jackasses (Serres et al., 2002; Miró et al., 2009).

The seminal plasma composition varies among different ejaculate fractions as well as between individuals, and could be one of the determinants of individual variation observed between stallions when using freezing-thawed semen (Aurich et al., 1996).

The jackass ejaculate consists of about five consecutive semen splashes, featuring three fractions: pre-sperm, sperm-rich and post-sperm (Mann et al., 1963). The fluid from the bulbourethral glands is the first to be released, followed by secretions from the epididymis and ampullae that compose the sperm-rich fraction, while the secretion of vesicular glands appears at the end of ejaculation (Mann et al., 1963; Magistrini et al., 2000)

Aiming to eliminate the deleterious effects of seminal plasma on sperm cells during semen storage, as well as the damage caused by centrifugation, the use of the sperm-rich fraction of the ejaculate obtained by the split-ejaculate method seems to be a good alternative.

Although it represents only $43.6 \%$ of the total volume of the ejaculation, the sperm-rich fraction contains $73.2 \%$ of the total amount of sperm in the ejaculate of stallions (Kosiniak, 1975 ) and $94 \%$ of sperm in $57.6 \%$ of the jackass total ejaculate volume (Mello, 1998). In addition, Tischner et al. (1974) reported the presence of minor bacterial semen contamination when open artificial vaginas are used for semen collection.

Although several studies have evaluated the characteristics of different fractions of stallion ejaculate (Tischner et al. 1974; Lindeberg et al., 1999; Kareskoski et al., 2005; Kareskoski and Katila, 2008), studies regarding jackasses are scarce (Mann et al., 1963; Mello, 1998).
Therefore, the aim of this study was to evaluate the physical and morphological characteristics of the sperm-rich fraction of Pêga jackasses.

\section{MATERIAL AND METHODS}

The experiment was conducted in Lagoa Dourada, Minas Gerais, Brazil, from September 2010 to February 2011.

Five Pêga jackasses, aged between 5 and 17 years, were used as semen donors. Their fertility was proven by good pregnancy rates.

To collect the sperm-rich fraction of the ejaculate, an open model artificial vagina (Fig. 1) adapted from Tischner et al. (1974) was used. It consisted of a thick rubber cylinder with $28 \mathrm{~cm}$ in length and $14 \mathrm{~cm}$ in diameter with a metal valve on one side. A sterile and disposable plastic bag with $25 \mathrm{~cm}$ in width and $35 \mathrm{~cm}$ in length was placed inside it. The semen collections were carried out 2 to 3 times a week, using an immobilized jenny (Fig. 2) or dummy. A plastic flask of $14 \mathrm{~cm}$ in diameter and capacity of $2.0 \mathrm{~L}$ was used to collect the sperm-rich fraction, composed by the first three jets ejaculated (Fig. 3 ). After collection, the plastic flask was sent to a laboratory and the plastic bag containing the semen was placed in a water bath at $37^{\circ} \mathrm{C}$. The semen was submitted to physical assessment (motility and vigor) using optical microscopes. The volume of the sperm-rich fraction was measured using graduated glass tubes.

To assess sperm concentration, a semen aliquot of $20 \mu \mathrm{L}$ was dissolved into $8 \mathrm{~mL}$ of saline formaldehyde buffered solution (1:400), and the number of sperm $/ \mathrm{mL}$ was determined after counting spermatozoa in a haemocytometer (Neubauer chamber).

After the physical assessment, the fresh semen was diluted (1:1) in skim milk - glucose (Kenney et al., 1983) or a lactose-egg yolk extender (Nagase and Graham, 1964) without glycerol, and sperm motility and vigor were evaluated after the dilution of the semen. Based on semen motility, the number of potential doses, containing 400 or $800 \times 10^{6}$ spermatozoa, was calculated per each ejaculate. Sperm morphology was evaluated in wet preparations under immersion in phase contrast microscope, with magnification of $1000 \mathrm{X}$, using fresh semen 
samples preserved in formaldehyde saline buffered solution (Hancock, 1957). After this procedure, 200 cells were counted for each preparation to assess the percentage of normal sperm, as well as acrosome, head, mid-piece, proximal cytoplasmatic droplet, distal cytoplasmatic droplet and tail defects (Fig. 4), according to Kenney et al. (1983).

Statistical analysis was performed using the SAS (Statistical, 1999), with significance level of $95 \%$ $(\mathrm{P}<0.05)$ and using the General Linear Models (GLM) for the analysis of variables. The values were expressed as mean \pm standard error. The percentage values were transformed into arcsine $\sqrt{ } \%$ before the analysis. Quantitative variables were analyzed using the GLM procedure. For comparing two means, the Student " $\mathrm{t}$ " test was used, and to compare three or more means, the Student-Newman-Keuls (SNK) test was used. For sperm vigor, a nonparametric statistical analysis was used; the Kruskal-Wallis test was used when comparing more than two means and the Wilcoxon test for comparison of two means.

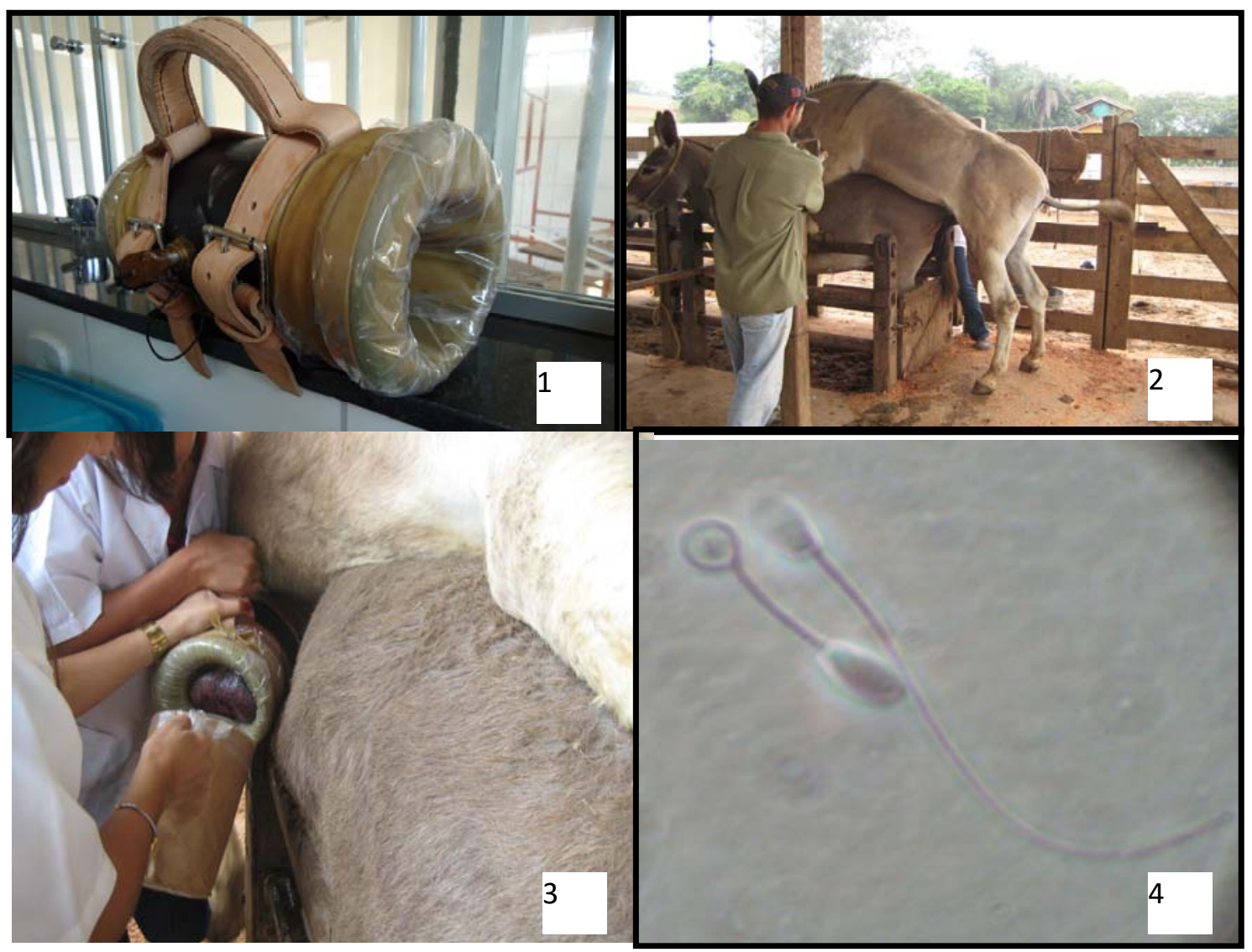

Figure 1. Open model artificial vagina. Figure 2. Semen collection using an immobilized jenny. Figure 3. Visual identification and collection of the sperm-rich fraction in a plastic flask. Figure 4. Morphological evaluation in phase contrast microscopy. Tail defect (arrow) and normal spermatozoa.

\section{RESULTS AND DISCUSSION}

The physical characteristics of the sperm-rich fraction of Pêga jackasses obtained by the splitejaculate method are presented in Table 1. It was observed that all the parameters evaluated differed $(\mathrm{P}<0.05)$ between the five jackasses. The same was observed for the morphological characteristics of semen from the sperm-rich fraction (Tab. 2), and only the percentage of head defects was similar $(\mathrm{P}>0.05)$ between jackasses. 
Reproductive biology...

Table 1. Physical characteristics of semen, and insemination doses produced per sperm-rich fraction of Pêga jackasses

\begin{tabular}{|c|c|c|c|c|c|c|}
\hline \multirow{2}{*}{ Parameter } & \multicolumn{5}{|c|}{ Jackass } & \multirow{2}{*}{ Total } \\
\hline & 1 & 2 & 3 & 4 & 5 & \\
\hline $\mathrm{N}^{\circ}$ ejaculates & 27 & 19 & 32 & 29 & 23 & 130 \\
\hline $\mathrm{N}^{\circ}$ mounts/ejaculate & $1.30 \pm 0.11 \mathrm{ab}$ & $1.63 \pm 0.13 \mathrm{a}$ & $1.34 \pm 0.10 \mathrm{ab}$ & $1.07 \pm 0.10 \mathrm{~b}$ & $1.09 \pm 0.12 \mathrm{~b}$ & $1.27 \pm 0.05$ \\
\hline Semen volume $(\mathrm{mL})$ & $12.04 \pm 1.59 \mathrm{~d}$ & $28.60 \pm 1.89 b$ & $17.80 \pm 1.46 \mathrm{c}$ & $10.10 \pm 1.53 \mathrm{~d}$ & $38.98 \pm 1.72 \mathrm{a}$ & $20.21 \pm 1.17$ \\
\hline Motility (\%) & $81.48 \pm 1.07 \mathrm{c}$ & $83.89 \pm 1.30 \mathrm{bc}$ & $85.78 \pm 0.99 \mathrm{ab}$ & $83.79 \pm 1.03 \mathrm{bc}$ & $87.83 \pm 1.15 \mathrm{a}$ & $84.53 \pm 0.51$ \\
\hline Vigor $(0-5)$ & $4.15 \pm 0.08 \mathrm{~d}$ & $4.31 \pm 0.10 \mathrm{~cd}$ & $4.56 \pm 0.08 \mathrm{ab}$ & $4.48 \pm 0.08 \mathrm{bc}$ & $4.78 \pm 0.09 \mathrm{a}$ & $4.46 \pm 0.04$ \\
\hline Motility post-dilution (\%) & $76.43 \pm 0.97 \mathrm{c}$ & $78.08 \pm 1.24 \mathrm{bc}$ & $81.92 \pm 0.87 \mathrm{a}$ & $80.43 \pm 0.93 \mathrm{ab}$ & $82.94 \pm 1.08 \mathrm{a}$ & $80.10 \pm 0.50$ \\
\hline $\mathrm{Sptz} / \mathrm{mL}\left(\mathrm{x} 10^{6}\right)$ & $740.00 \pm 66.32 \mathrm{~b}$ & $722.11 \pm 79.06 \mathrm{~b}$ & $946.25 \pm 60.92 \mathrm{~b}$ & $1203.45 \pm 63.99 \mathrm{a}$ & $756.09 \pm 71.85 \mathrm{~b}$ & $894.38 \pm 33.97$ \\
\hline Motile sptz/mL $\left(\times 10^{6}\right)$ & $587.78 \pm 58.07 \mathrm{~b}$ & $599.39 \pm 69.23 \mathrm{~b}$ & $788.67 \pm 53.34 \mathrm{~b}$ & $990.59 \pm 56.04 \mathrm{a}$ & $651.83 \pm 62.92 \mathrm{~b}$ & $740.12 \pm 29.36$ \\
\hline Total sptz/ejaculate $\left(x 10^{9}\right)$ & $8.47 \pm 1.59 \mathrm{c}$ & $19.63 \pm 1.90 \mathrm{~b}$ & $16.18 \pm 1.46 \mathrm{~b}$ & $11.26 \pm 1.53 \mathrm{c}$ & $28.38 \pm 1.72 \mathrm{a}$ & $16.14 \pm 0.93$ \\
\hline Motile sptz/ejaculate $\left(\times 10^{9}\right)$ & $6.69 \pm 1.28 \mathrm{c}$ & $16.06 \pm 1.52 \mathrm{~b}$ & $13.38 \pm 1.17 \mathrm{~b}$ & $9.18 \pm 1.23 \mathrm{c}$ & $24.14 \pm 1.38 \mathrm{a}$ & $13.35 \pm 0.77$ \\
\hline Semen volume/dose $\left(400 \times 10^{6}\right)$ & $0.82 \pm 0.07 \mathrm{a}$ & $0.84 \pm 0.08 \mathrm{a}$ & $0.57 \pm 0.06 \mathrm{~b}$ & $0.47 \pm 0.06 \mathrm{~b}$ & $0.76 \pm 0.07 \mathrm{a}$ & $0.67 \pm 0.03$ \\
\hline Extender volume/dose $\left(400 \times 10^{6}\right)$ & $21.18 \pm 0.07 \mathrm{~b}$ & $21.16 \pm 0.08 \mathrm{ab}$ & $21.43 \pm 0.06 \mathrm{a}$ & $21.53 \pm 0.06 \mathrm{a}$ & $21.24 \pm 0.07 \mathrm{~b}$ & $21.33 \pm 0.03$ \\
\hline Semen volume/dose $\left(800 \times 10^{6}\right)$ & $1.64 \pm 0.13 \mathrm{a}$ & $1.68 \pm 0.16 \mathrm{a}$ & $1.11 \pm 0.12 \mathrm{~b}$ & $0.94 \pm 0.13 \mathrm{~b}$ & $1.53 \pm 0.14 \mathrm{a}$ & $1.34 \pm 0.07$ \\
\hline Extender volume/dose $\left(800 \times 10^{6}\right)$ & $20.36 \pm 0.13 b$ & $20.32 \pm 0.16 \mathrm{~b}$ & $20.89 \pm 0.12 \mathrm{a}$ & $21.06 \pm 0.13 \mathrm{a}$ & $20.47 \pm 0.14 \mathrm{~b}$ & $20.66 \pm 0.07$ \\
\hline $\mathrm{N}^{\circ}$ doses/ejaculate $\left(400 \times 10^{6}\right)$ & $16.73 \pm 3.19 \mathrm{c}$ & $40.23 \pm 3.81 \mathrm{~b}$ & $33.41 \pm 2.93 b$ & $22.95 \pm 3.08 \mathrm{c}$ & $60.42 \pm 3.46 \mathrm{a}$ & $33.39 \pm 1.93$ \\
\hline $\mathrm{N}^{0}$ doses/ejaculate $\left(800 \times 10^{6}\right)$ & $8.36 \pm 1.60 \mathrm{c}$ & $20.05 \pm 1.90 \mathrm{~b}$ & $16.72 \pm 1.47 \mathrm{~b}$ & $11.50 \pm 1.54 \mathrm{c}$ & $30.21 \pm 1.73 \mathrm{a}$ & $16.69 \pm 0.97$ \\
\hline
\end{tabular}

Means followed by different letters in the line to differentiate between them $(\mathrm{P}<0.05)$.

Table 2. Morphological characteristics of fresh semen from the sperm-rich fraction of Pêga jackasses

\begin{tabular}{|c|c|c|c|c|c|c|}
\hline \multirow{2}{*}{$\begin{array}{c}\text { Sperm } \\
\text { Morphology }\end{array}$} & \multicolumn{5}{|c|}{ Jackass } & \multirow{2}{*}{ Total } \\
\hline & 1 & 2 & 3 & 4 & 5 & \\
\hline $\mathrm{N}^{\circ}$ ejaculates & 11 & 11 & 12 & 13 & 12 & 59 \\
\hline Normal (\%) & $90.42 \pm 0.70 b$ & $92.15 \pm 0.70 b$ & $91.75 \pm 0.67 b$ & $82.37 \pm 0.65 c$ & $96.40 \pm 0.67 \mathrm{a}$ & $90.46 \pm 0.69$ \\
\hline PCD (\%) & $1.50 \pm 0.41 b c$ & $1.89 \pm 0.41 \mathrm{~b}$ & $0.81 \pm 0.39 b c$ & $4.68 \pm 0.38 \mathrm{a}$ & $0.56 \pm 0.39 \mathrm{c}$ & $1.94 \pm 0.26$ \\
\hline DCD (\%) & $1.80 \pm 0.29 \mathrm{a}$ & $1.45 \pm 0.29 \mathrm{a}$ & $1.17 \pm 0.28 \mathrm{a}$ & $1.51 \pm 0.27 \mathrm{a}$ & $0.24 \pm 0.28 b$ & $1.22 \pm 0.14$ \\
\hline MP (\%) & $2.56 \pm 0.44 b$ & $1.45 \pm 0.44 \mathrm{c}$ & $1.83 \pm 0.42 b c$ & $5.85 \pm 0.41 \mathrm{a}$ & $0.97 \pm 0.42 \mathrm{c}$ & $2.61 \pm 0.30$ \\
\hline Tail (\%) & $2.23 \pm 0.37 b$ & $2.53 \pm 0.37 b$ & $2.89 \pm 0.36 \mathrm{~b}$ & $4.81 \pm 0.34 \mathrm{a}$ & $1.11 \pm 0.36 \mathrm{c}$ & $2.76 \pm 0.23$ \\
\hline Head (\%) & $1.44 \pm 0.25$ & $0.51 \pm 0.25$ & $1.31 \pm 0.24$ & $0.69 \pm 0.23$ & $0.64 \pm 0.24$ & $0.91 \pm 0.12$ \\
\hline $\begin{array}{c}\text { Acrosome } \\
(\%)\end{array}$ & $0.00 \pm 0.05 \mathrm{~b}$ & $0.00 \pm 0.05 b$ & $0.22 \pm 0.05 \mathrm{a}$ & $0.06 \pm 0.05 \mathrm{ab}$ & $0.08 \pm 0.05 \mathrm{ab}$ & $0.07 \pm 0.02$ \\
\hline
\end{tabular}

Means followed by different letters in the line to differentiate between them $(\mathrm{P}<0.05)$.

PCD - Proximal cytoplasmic droplet, DCD - Distal cytoplasmic droplet.

In stallions, Mann et al. (1963) and Pickett et al. (1970) reported significant variations in the physical parameters of semen between individuals and between ejaculates from the same individual. In addition, Rossi (2008) observed a high number of individual variations between five Pêga jackasses for different semen characteristics evaluated, such as sperm concentration, motile sperm concentration, total sperm per ejaculate and total motile sperm per ejaculate, similar to that observed in the present experiment.

Regarding the sexual behavior of jackasses used in this experiment, it was observed that the number of mounts per ejaculate differed $(\mathrm{P}<0.05)$ between jackasses, with an average of 1.27 mounts/ejaculate. For stallions with normal libido, Pickett et al. (1976) reported an average of 1.8 mounts/ejaculates. Thus, the results obtained in this study showed the jackasses accepted the open artificial vagina used for the collection. An excessive number of mounts without ejaculation is not desirable since it can increase the volume of seminal plasma, without, however, contributing to an increase in the total number of sperm/ejaculate (Ionata et al., 1991).

Few studies have characterized the sperm-rich fraction of jackasses. In this experiment, it was observed that the volume of this ejaculate portion ranged from 10.10 to $38.98 \mathrm{~mL}$, with mean volume of $20.21 \mathrm{~mL}$. As was expected, the volume found in this study was less than the total ejaculate volume described by Morais et al. (1994), of 59.88mL; Rossi (2008), ranging from 33.46 to $61.56 \mathrm{~mL}$; and Canisso et al. (2010), of $47.30 \mathrm{~mL}$. Trimeche (1996) studied Poitou jackasses and observed sperm-rich fractions with volumes ranging from 6 to $23 \mathrm{~mL}$, less than the variation observed in this experiment. For the first two jets ejaculated by the three jackasses, Beker (1997) observed volumes between 9.42 and $25.75 \mathrm{~mL}$, and Mello (1998) obtained volumes varying between 9.72 and $47.00 \mathrm{~mL}$, for five jackasses. Although the sperm-rich fraction in this experiment included the third jet, the semen volume variation is similar to that 
described by Mello (1998) for the first two jets ejaculated. It was observed during this experiment that changes in volume were more associated with the individual than with the sexual stimulation before semen collection, since larger volumes of sperm-rich fraction were not associated with jackasses that had higher number of mounts per ejaculate.

In relation to total sperm motility (range 0$100 \%$ ) for fresh semen from the sperm-rich fraction, there was a variation from 81.48 to $87.83 \%$, with mean value of $84.53 \%$, higher than those described by Morais et al. (1994), Rossi (2008) and Canisso et al. (2010) for total ejaculate of Pêga jackasses.

As for total motility, the mean sperm vigor from the sperm-rich fraction (4.46) observed in this experiment was higher than that recorded by Canisso et al. (2010), but similar to values reported by Morais et al. (1994) and Rossi (2008), assessing the total ejaculate. After semen dilution, a slight reduction in sperm motility was observed, with mean value of $80.10 \%$ (76.43 to $82.94 \%)$. The interval between semen dilution and assessment may have been insufficient for the adjustment of sperm cells to the extender.

For the first two jets of the sperm-rich fraction, Beker (1997) observed total motility after semen dilution between 77.06 and $81.84 \%$, and the value obtained in this experiment is within the range shown by this study.

The sperm concentration of Pêga jackass total ejaculate varies from $69.46 \times 10^{6}$ in jackass 2 and $305.24 \times 10^{6}$ in jackass 4 (Rossi, 2008) to 444.11 x $10^{6} \mathrm{sptz} / \mathrm{mL}$ (Morais et al., 1994). In this experiment, the sperm concentration of the sperm-rich fraction of jackasses ranged from 722.11 to $1203.45 \times 10^{6} \mathrm{sptz} / \mathrm{mL}$, with mean value of $894.38 \times 10^{6} \mathrm{sptz} / \mathrm{mL}$, higher than those previously described for the total ejaculate.

Mello (1998) reported sperm concentrations ranging from 246.25 to $930.05 \times 10^{6} \mathrm{sptz} / \mathrm{mL}$ for the first two jets of Pêga jackass ejaculate. In this experiment, for the same jackass breed, higher mean sperm concentration was observed. Perhaps, the presence of the third splash associated with the first two ones, in the present study, was responsible for this difference. Among the five jackasses assessed, the highest sperm concentration was observed in jackass 4 , higher $(\mathrm{P}<0.05)$ than the other jackasses, which were similar $(\mathrm{P}>0.05)$ to each other.

The semen and extender volume necessary to produce insemination doses of $22 \mathrm{~mL}$ containing 400 or $800 \times 10^{6}$ motile sptz also differed $(\mathrm{P}<0.05)$ between jackasses. Thus, jackasses 1,2 and 5 require higher $(\mathrm{P}<0.05)$ semen volume/insemination dose compared to jackasses 3 and 4. The opposite was observed for the extender volume.

In this experiment, the total number of sperm cells present in the sperm-rich fraction of Pêga jackass ejaculate ranged from 8.47 to $28.38 \times 10^{9}$ spermatozoa, with mean value of $16.14 \times 10^{9}$. For the sperm-rich fraction represented by the first two jets, using ejaculates of the same jackass breed, Mello (1998) reported total sperm number from 9.04 to $14.35 \times 10^{9}$. Thus, the high number of spermatozoa in the sperm-rich fraction observed in this experiment is probably due to the inclusion of the third jet of the spermrich fraction of the ejaculate.

It is worth mentioning that the total sperm number present in the fractionated ejaculate (16.14 x $\left.10^{9} \mathrm{sptz}\right)$ was lower than that described by Morais et al. (1994) for Pêga jackass ejaculates $\left(24.88 \times 10^{9}\right)$. However, it was higher than that described later by Canisso et al. (2010) for the total ejaculate of the same jackass breed (10.3 x $\left.10^{9} \mathrm{sptz}\right)$, demonstrating that the spermrich fraction accounts for a high percentage of the total concentration of sperm in the ejaculate . A similar result was obtained by Mello (1998), when the sperm-rich fraction of jackasses accounted for $94 \%$ of total ejaculated sperm in a volume of approximately $57.6 \%$ of the ejaculate.

Thus, the fractioned collection does not entail great loss in the total number of sperm collected, as well as the potential number of females to be inseminated continues to be similar in relation to the total semen collection. When the total ejaculate of five Pêga jackasses was collected, Rossi (2008) reported a production of 5.60 to 27.66 insemination doses $\left(400 \times 10^{6}\right.$ motile sptz)/ejaculate. For the same sperm concentration/insemination dose, the sperm-rich fraction used in this experiment was able to produce from 16.73 to 60.42 insemination doses, with mean of 33.39 doses. When an insemination dose containing $800 \times 10^{6}$ spermatozoa was used, 
this number was reduced by half. Both concentration doses brought benefits, since the semen collection and dilution were responsible for maximizing the use of jackass semen, even when using just the sperm-rich fraction.

Regarding the sperm morphology of the spermrich fraction, it was observed that, except for jackass 4 , the other jackasses had more than $90 \%$ of normal sperm morphology. The percentage of abnormal morphology is relatively low in jackasses, around $16 \%$ in most reports (Kreuchauf, 1984; Henry et al., 1987; Morais et al., 1994; Gastal et al., 1997; Rossi, 2008). However, for the first two jets of the sperm-rich fraction of jackasses, Mello (1998) found $71.47 \%$ of normal sperm morphology, lower than the mean values observed in this experiment $(90.46 \%)$ for the first three jets of the same ejaculate fraction.

Sperm quality has a significant importance and can alter reproductive performance. In this sense, Haag (1959) found higher pregnancy rates associated with stallions that had motility higher than $50 \%$ and percentage of abnormal sperm morphology below 40\%. However, Bielanski (1975) observed that stallions with high levels of morphological abnormalities could have excellent fertility. Later, Kenney et al. (1983) found that sperm concentration associated with the percentage of normal sperm morphology and motility were the semen characteristics that best explained variations in conception rates obtained at the end of the breeding season. Accordingly, other authors have shown that sperm motility and morphology are the most relevant semen characteristics (Jasko et al., 1990). However, no studies have correlated the percentage of sperm morphology with the fertility of jackasses.

In conclusion, this study showed that the spermrich fraction of Pêga jackasses was characterized by high-quality sperm and reinforced the advantages of this fraction in the semen processing associated with its high sperm concentration $/ \mathrm{mL}$, which reaches an adequate dilution rate that can minimize the deleterious effects of seminal plasma during semen storage, excluding the necessity of semen centrifugation.

\section{ACKNOWLEDGEMENTS}

Laura Carvalho was sponsored by a postgraduate scholarship by FAPEMIG, Brazil. The authors thank Tarcísio Resende and Haras Lagoa Dourada Farm for the animals and farm unit used for this experiment.

\section{REFERENCES}

AURICH, J.E.; KÜHNE, A.; HOPPE, H. et al. Seminal plasma affects membrane integrity and motility of equine spermatozoa after cryopreservation. Theriogenology, v.46, p.791-797, 1996.

BEKER, A.R.C.L. Efeitos de diferentes concentrações espermáticas e de antibióticos sobre a longevidade do sêmen asinino (Equus asinus), resfriado a 5 C. 1997. 91f. Dissertação (Mestrado em Medicina Veterinária) - Escola de Veterinária, Universidade Federal de Minas Gerais, Belo Horizonte, MG.

BERGERON, A.; CRÊTE, M.H.; BRINDLE, Y. et al. Low density lipoprotein fraction from hen's egg yolk decreases the binding of the major proteins of bovine seminal plasma to sperm and prevents lipid efflux from the sperm membrane. Biol. Reprod., v.70, p.708$717,2004$.

BIELANSKI, W. The evaluation of stallion semen in aspects of fertility control and its use for artificial insemination. In: INTERNATIONAL SYMPOSIUM ON EQUINE REPRODUCTION, 1., 1974, Cambridge. Proceedings... Cambridge: King's College, 1975. p.19-24.

CANISSO, I.F.; CARVALHO, G.R.; DAVIES MOREL, M.C.G. et al. Sexual behavior and ejaculate characteristics in Pêga donkeys (Equus asinus) mounting estrous horse mares (Equus caballus). Theriogenology, v.73, p.56-63, 2010.

GASTAL, M.O.; HENRY, M.; BEKER, A.R. et al. Effect of ejaculation frequency and season on donkey jack semen. Theriogenology, v.47, p.627-638, 1997.

HAAG, F.M. Evaluation of "dismount" semen in thoroughbred horse breeding. J. Am. Vet. Med. Assoc., v.1, p.312-314, 1959.

HANCOCK, J.L. The morphology of boar spermatozoa. J. R. Microsc. Soc., v.76, p.84-97, 1957.

HENRY, M.; OLIVEIRA, M.M.F.; DIAZ, A.P. et al. Comportamento de jumentos no período de cortejo e ato sexual. In: CONGRESSO BRASILEIRO DE REPRODUÇÃO ANIMAL, 7., 1987, Belo Horizonte. Anais... Belo Horizonte: Colégio Brasileiro de Reprodução Animal, 1987. p.71. 
IONATA, L.M.; ANDERSON, T.M.; PICKETT, B.W. et al. Effect of supplementary sexual preparation on semen characteristics of stallions. Theriogenology, v.36, p.923-937, 1991.

JASKO, D.J.; HATHAWAY, J.A.; SACHALTENBRAND, V.I. Effect of seminal plasma and egg yolk on motion characteristics of cooled stallion spermatozoa. Theriogenology, v.37, p.12411252, 1992.

JASKO, D.J.; LEIN, D.H.; FOOTE, R.H. Determination of the relationship between sperm morphologic classifications and fertility in stallions: 66 cases (1987-1988). J. Am. Vet. Med. Assoc., v.197, p.389-394, 1990.

KARESKOSKI, A.M.; REILAS, T.; SANKARI, S. et al. Composition of fractionated stallion ejaculates. Anim. Reprod. Sci., v.89, p.228-230, 2005.

KARESKOSKI, M.; KATILA T. Components of stallion seminal plasma and the effects of seminal plasma on sperm longevity. Anim. Reprod. Sci., v.107, p.249-256, 2008.

KENNEY, R.M.; HURTGEN, J.P.; PIERSON, R. et al. Society for theriogenology manual for clinical fertility evaluation of the stallion. Hastings: Society for Theriogenology, 1983. 100p.

KOSINIAK, K. Characteristics of the successive jets of ejaculated semen of stallions. J. Reprod. Fertil., Suppl. 23, p.59-61, 1975.

KREUCHAUF, A. Reproductive physiology in the jackass. Anim. Res. Develop., v.20, p.51-78, 1984.

LINDEBERG, H.; KARJALAINEN, H.; KOSKINEN, E. et al. Quality of stallion semen obtained by a new semen collection phantom (Equidame ${ }^{\circledR}$ ) versus a Missouri ${ }^{\circledR}$ artificial vagina. Theriogenology, v.51, p.1157-1173, 1999.

MAGISTRINI, M.; LINDEBERG, H.; KOSKINEN, E. et al. Biophysical and $1 \mathrm{H}$ magnetic resonance spectroscopy characteristics of fractionated stallion ejaculates. J. Reprod. Fertil., Suppl. 56, p.101-110, 2000.

MANN, T.; MINOTAKIS, C.S.; POLGE, C. Semen composition and metabolism in the stallion and jackass. J. Reprod. Fertil., v.5, p.109-122, 1963.

MELLO, S.L.V. Efeito da coleta fracionada de sêmen $e$ de dois diluentes sobre a longevidade de espermatozoides de jumentos (Equus asinus) resfriados a $5^{\circ} \mathrm{C} .1998 .97 \mathrm{f}$. Dissertação (Mestrado em Medicina Veterinária) - Escola de Veterinária da Universidade Federal de Minas Gerais, Belo Horizonte, MG.
MIRÓ, J.; TABERNER, E.; RIVERA, M. et al. Effects of dilution and centrifugation on the survival of spermatozoa and the structure of motile sperm cell subpopulations in refrigerated Catalonian donkey semen. Theriogenology, v.72, p.1017-1022, 2009.

MORAIS, R.N.; MUCCIOLO. R.G.; VIANA, W.G. Biologia reprodutiva de jumentos. III. $\mathrm{pH}$, osmolaridade e níveis de eletrólitos no sêmen. Braz. J. Vet. Res. Anim. Sci., v.31, p.145-151, 1994.

NAGASE, H.; GRAHAM, E.F. Pellet semen: comparision of different extenders and processes on fertility of bovine spermatozoa. In: INTERNATIONAL CONGRESS ANIMAL REPRODUCTION AND ARTIFICIAL INSEMINATION, 5., 1964, Trento. Proceedings... Trento: [s.n.], 1964. p.387-391.

PICKETT, B.W.; FAULKNER, L.C.; SEIDEL, G.E. et al. Reproductive physiology of the stallion: IV. seminal and behavior characteristics. J. Anim. Sci., v.43, p.617-625, 1976.

PICKETT, B.W.; FAULKNER, L.C.; SUTHERLAND, T.M. Effect of month and stallion on seminal characteristics and sexual behavior. J. Anim. Sci., v.31, p.713-728, 1970.

ROSSI, R. Comparação de dois diluidores na fertilidade de éguas inseminadas com sêmen asinino a fresco ou resfriado. 2008. 209f. Dissertação (Mestrado em Medicina Veterinária) - Escola de Veterinária, Universidade Federal de Minas Gerais, Belo Horizonte, MG.

SAS. Statistical analysis system. Version 5. Cary: SAS Institute, 1999.

SERRES, C.; RODRÍGUEZ, A.; ALVAREZ, A.L. et al. Effect of centrifugation and temperature on the motility and plasma membrane integrity of Zamoranoleone's donkey semen. Theriogenology, v.58, p.329332, 2002.

TISCHNER, M.; KOSINIAK, K.; BIELÁNSKI, W. Analysis of the pattern of ejaculation in stallion. $J$. Reprod. Fertil., v.41, p.329-335, 1974.

TRIMECHE, A. Estudes sur la fertilite et la cryopreservation du sperme du baudet du Poitou. 1996. 136f. Tesis (doctoral). - Universidad de Rennes. Francia. 